Hevko Ihor Vasilievich. Formation of the main directions of professional culture of future bachelors of motor transport. Journal of Education, Health and Sport. 2020;10(5):332-339. eISSN 2391-8306. DOI http://dx.doi.org/10.12775/JEHS.2020.10.05.035 https://apcz.umk.pl/czasopisma/index.php/JEHS/article/view/JEHS.2020.10.05.035

https://zenodo.org/record/4079152

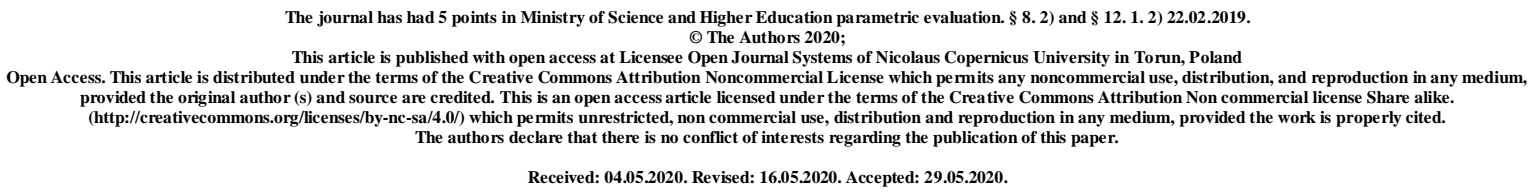

UDK 378.147

\title{
FORMATION OF THE MAIN DIRECTIONS OF PROFESSIONAL CULTURE OF FUTURE BACHELORS OF MOTOR TRANSPORT
}

\author{
Ihor Vasilievich Hevko
}

Ternopil Volodymyr Hnatiuk National Pedagogical University

\begin{abstract}
In the presented materials of the publication an attempt is made to substantiate the peculiarities of the formation of the professional culture of future bachelors of road transport. The most effective educational components of their professional training are analyzed. Relevant recommendations for improving the organization of the educational process on the basis of credit transfer technology are offered.

Key words: credit-transfer technology of education; components; professional culture; preparation; future bachelors of motor transport; transport.
\end{abstract}




\title{
ФОРМУВАННЯ ОСНОВНИХ НАПРЯМКІВ ПРОФЕСІЙНОЇ КУЛЬТУРИ МАЙБУТНІХ БАКАЛАВРІВ АВТОМОБІЛЬНОГО ТРАНСПОРТУ
}

\author{
Гевко Ігор Васильович
}

Тернопільського національного педагогічного університету імені Володимира Гнатюка

У представлених матеріалах публікації здійснено спробу обгрунтувати особливості формування професійної культури майбутніх бакалаврів автомобільного транспорту. Проаналізовано найбільш ефективні навчальні компоненти їх фахової підготовки. Пропонуються відповідні рекомендації з удосконалення організації навчально-виховного процесу на засадах кредитно-трансферної технології.

Ключові слова: кредитно-трансферна технологія навчання; компоненти; професійна культура; підготовка; майбутні бакалаври автомобільного транспорту; транспорт.

Formulation of the problem. Ukraine's integration into the European educational space places the priority of the human personality at the center of domestic pedagogy. The 21 st century makes new demands on education. The world's leading countries are mastering the strategy of sustainable human development. Mankind is noticeably changing its orientation towards democracy, raising the authority of the individual, his culture, tolerance and market relations, and affirms them as important directions of the new world dynamics. Living in a democracy, market, the latest information technology is becoming an inevitable prospect [1]. Therefore, the problem of forming a culture of graduates of pedagogical universities is relevant.

Reforming higher education in accordance with the provisions of credit-transfer technology of education is aimed at modernizing the content of training of future professionals in accordance with modern world requirements and the introduction of European mechanisms for evaluating and comparing learning outcomes [2]. Fierce competition in the market of high-quality educational services increases the requirements for the formation of professional culture of future bachelors of road transport. 
Analysis of recent research. The works of domestic and foreign authors: S. Honcharenko, I. Zyazyun, N. Kuzmina, O. Pekhota, V. Semichenko, V. Slastyonin and others are devoted to the problem of professional training of future specialists.

In recent years, separate works have appeared in the scientific literature, which interprets the concept of "professional culture" and the provisions of the theory of professional and pedagogical competence of future bachelors of road transport (A. Asherov, I. Vasiliev, E. Zeer, O. Kovalenko, O. Malenko, N. Nichkalo, O. Shcherbak). However, in these works insufficient attention is paid to the formation of professional culture in future bachelors of road transport.

The purpose of the article is to analyze the basic principles of professional culture in future bachelors of road transport.

Presenting main material. Professional culture is a creative vision and rethinking of problems that arise in the absence of this culture. Therefore, the culture of future bachelors of road transport presupposes the presence of modern thinking, which is, first of all, the ability to think correctly and deeply, independently analyze phenomena and processes, see in them the main and special, abandon stamps and more. Thus, the professional culture of future bachelors of road transport can be identified: as the acquisition by a future specialist of professional competencies, when they are organically combined with modern information technology and constitute his worldview; as the ability of the individual to creative thinking and constant self-improvement, self-education.

Training of future bachelors of motor transport involves the acquisition of professional knowledge, the formation of professional competence, the formation of professionally significant qualities necessary for participation in professional activities. However, the professional culture of future professionals, in our opinion, can not be simplified to a system of narrow professional knowledge, skills and abilities. This concept is broader and includes the full potential of the individual. Determining not only the cognitive interests of the student, professional culture determines his worldview, values, general life credo. Thus, professional culture can be considered as an integrated quality of personality.

Note that the professional culture of future bachelors of road transport has different levels of formation. The main level can be conditionally called informational. In addition, there are three blocks of requirements for the characteristics of future bachelors of road transport: to the individual; to the specialist (has the corresponding pedagogical and technical knowledge); to a professional (has modern educational technologies). 
In order to synthesize the general scheme of the process of formation of professional culture of future engineers-teachers in the field of transport, we will analyze the main aspects of such specialists and their relationship on the example of specialty 015.38 Vocational Education (Transport).

In structural terms, the concept of professional culture of future bachelors of road transport should include a number of components: professionalism, technical and pedagogical thinking, information training, sociability, and so on. However, these are only macrocomponents that reflect the general content of the professional training of future bachelors of road transport, and require internal filling of relevant disciplines. The specifics of training future bachelors of road transport is that he must have "deep knowledge not only in the field of professional activity, but also in the field of formalizing the tasks of transport process management and ensuring the functioning of transport systems at all levels" [3]. Thus, it expands the range of disciplines of the curriculum of the specialty "Vocational Education. Transport ", which will provide multifaceted training for future bachelors of road transport.

Consider the structural scheme of fundamental and professional training of bachelors specialty 015.38 Vocational education Transport (Fig. 1).

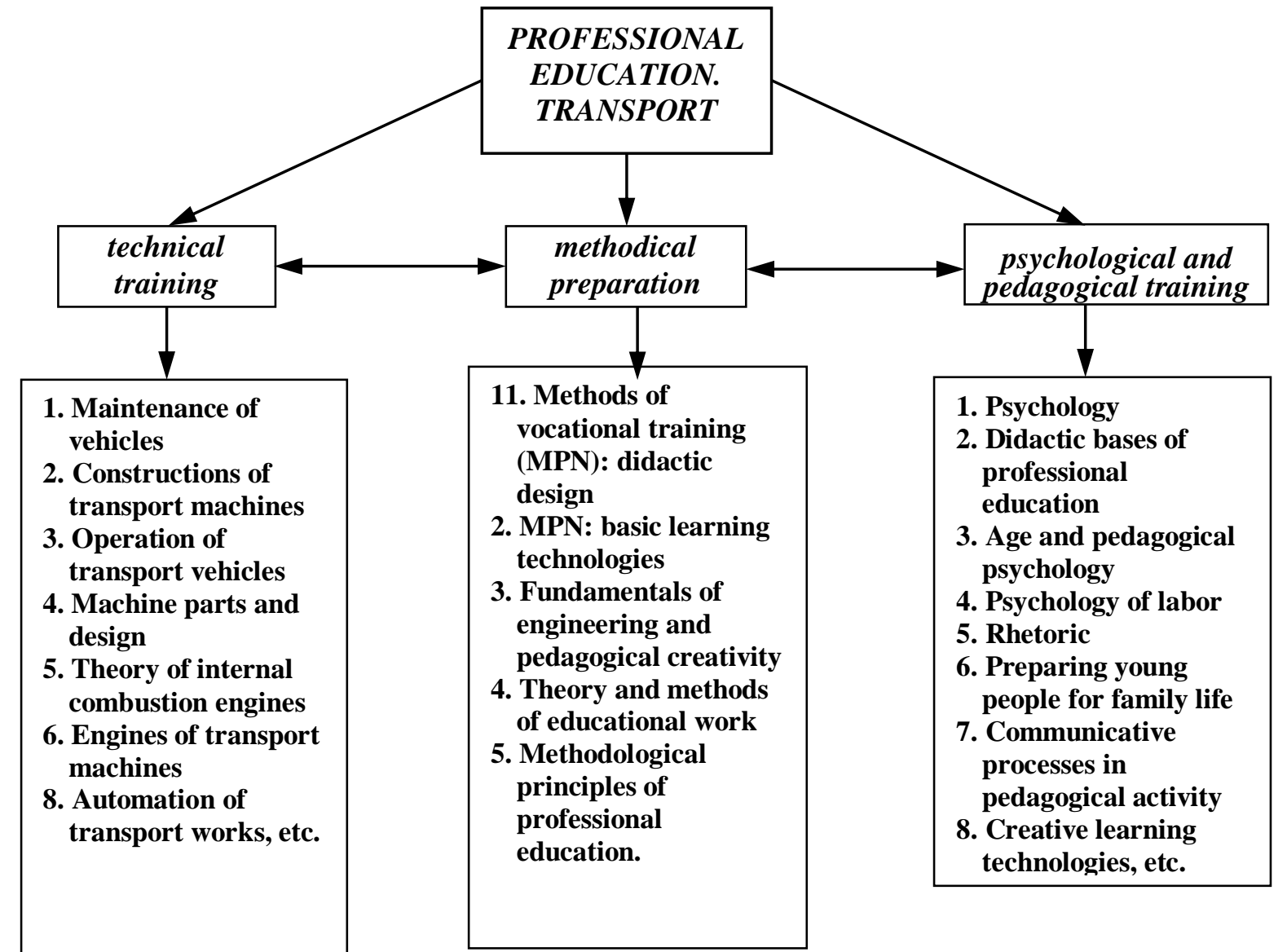

Fig.1. Block diagram of training future bachelors in specialty 015.38 Vocational education. Transport 
Based on this scheme, the most logically important (productive) educational components of the educational program, which form the professional culture of future professionals, in particular: technical, methodological and psychological-pedagogical. In terms of intensive development of road transport, increasing the volume of freight and passenger traffic, the emergence of modern methods of traffic management (logistics), the professional development of future bachelors of road transport depends on the nature (level) of its activity in the development of information and educational space. student at all stages of training, a higher degree of professional development is achieved, the transformation of vocational education into self-education, self-actualization and self-development.

For the preparation of bachelors specialty 015.38 Vocational education. Transport is studied in more than 70 disciplines, which leads to fragmentation of knowledge, excessive tautology and overload of students. Therefore, the main problem of the curriculum in the context of credit-transfer technology of education is the development of optimal structural and logical schemes of the educational process. The main essence of the changes made to the organization and content of the educational process is the structure and differentiation, in terms of the logical continuity of the program of basic (bachelor's level) and full (specialist and master's level) education.

Notwithstanding the above, it is advisable to make some reservations about the curriculum. For a pedagogical institution of higher education, the bachelor's degree cannot be final, because basic education does not give him the opportunity to get a job, ie to participate in the competition in the labor market. Yes, and four-year planning is a short time to prepare future bachelors of road transport, who would have high theoretical, practical and methodological knowledge

mproving fundamental and professional training is the main problem of the teaching staff of the Faculty of Engineering and Pedagogy of Ternopil National Pedagogical University named after Volodymyr Hnatyuk (TNPU). The essence of this problem is that the teacher should give students more information about modern information and educational technologies, laws and patterns, trends and concepts of development, ie generalize materials, rather than operate with statistics that can be helpful in characterizing phenomena or processes. This will reduce the number of subjects, integrate them and change approaches to the formation of professional culture of future bachelors of road transport.

An important aspect of the formation of professional culture of future bachelors of road transport is the use of new educational learning technologies in the field of interactive communication between teacher and student. It lies in individual work with the student, which 
reveals their creative potential, opportunities for self-replenishment of knowledge, the ability to work with scientific materials using modern educational technologies and appropriate tools. Students should not work on individual topics of the course or entire sections of the program, but get acquainted with the literature, which will expand their knowledge in a particular area and, accordingly, contribute to a better understanding of the basic principles and processes.

There is a problem of changing the psychology of students to study in higher education, and teachers - to use modern educational technologies, local environments and the global computer network Internet. In this regard, the individual approach to the organization of training and control of students' knowledge requires time and effort of teachers. Given this, it is important to reduce the classroom load of teachers and expand individual work with students, quality control of their knowledge obtained independently. Therefore, there is a need to reduce the number of students per teacher. This will automatically increase your bids. Are we ready to resolve this issue?

Also noteworthy is the problem of the volume of academic disciplines that students need to learn when acquiring a particular profession. Apparently, they do not need to re-study those subjects that have a general scientific direction and are studied in high school. At the same time, it would be better to organize research work of students, involving them in the department of scientific topics. The results of such work are the implementation of competitive research papers, preparation of term papers, master's theses, abstracts, articles and other scientific products.

Even during the implementation of these areas, the discrepancy with European education remains significant, so measures to implement the European experience should be systematic and rich in content, including internal university changes in the organization of education and scientific and methodological support.

Recently, the activity of teachers on the development of educational and methodological complexes has intensified. They include a curriculum upgraded in accordance with the requirements of the credit transfer system (ECTS). We consider the credit transfer system as a means of increasing student mobility during the transition from one curriculum to another; work programs, which contain information on the number of credits allocated for the study of a particular discipline with a division into classroom classes, individual and independent work; programs divided into meaningful modules that contain lecture and laboratory-practical topics; electronic educational and methodical complexes - texts of lectures, development of laboratory and practical classes, tasks for independent, current and 
final control and for individual educational and research work of students, recommended literature, etc.

A separate element is the ECTS system for assessing the quality of students' knowledge. In the process of preparing future bachelors of road transport, the traditional European stobal scale is adopted, which is used at the university. Distribution and substantiation of the number of points in the content modules and for each specific topic and type of activity contributes to the systematic work of students during the semester, as well as develops in them the culture and attitude to the acquisition of knowledge.

One of the components of continuous improvement of the educational process is the development by teachers of interactive electronic educational and methodological complexes in the main disciplines of bachelor's degree. They should be freely available in the electronic network of the university and be widely used in the educational process, both in lectures, laboratory and practical classes, and in the organization of individual and independent work of students.

In order to optimize the educational process and the effective use of modern information technology, the university has created a number of electronic reading rooms and classrooms, with the possible use of multimedia technologies. Special attention should be paid to courses on the program "Intel - learning for the future". The latter provides for training according to the project methodology on the basis of the State Standards of Education of Ukraine, contributes to the optimization of teaching technical and psychological-pedagogical disciplines.

Educational (technological, propaedeutic, pedagogical) practices are an integral part of expanding the professional training and formation of professional culture of future bachelors of road transport. 32 credits or almost $14 \%$ of the workload are allocated for their implementation in the bachelor's degree curriculum. Training practices give the opportunity to consolidate the theoretical material in conditions close to real, and the acquired skills to use in professional activities. In this regard, it is worth summarizing the experience gained over many years and consider how to optimize it so that the content is even more related to future production functions and typical tasks of future bachelors of road transport.

Work on improving the educational process is aimed at the development of professional science, preservation of the best national educational traditions. To implement these areas, it is necessary to use existing resources and global trends to optimize the modern culture of teaching and organization of the educational process. To this end, the scientific and pedagogical staff of the Engineering and Pedagogical Faculty of TNPU held several meetings 
and seminars for teachers on the use and implementation of credit-transfer technology of education.

Conclusions and prospects for further research. The directions of formation of professional culture of future bachelors of motor transport of the specialty Professional education are listed. Transport is just a few touches that should underlie the acquisition of knowledge and skills and the organization of the educational process on the basis of credittransfer technology, which, unlike traditional education, is gradually reoriented to the development of students' personalities, their creative qualities.

The development of an optimal model for the training of future bachelors of road transport in the context of credit transfer technology and bringing in line with European standards the content and form of training is a prospect for further exploration.

\section{Reference}

1. National doctrine of education development of Ukraine in the XXI century // Education of Ukraine. - № 29. - 2001. - P. 4-6.

2. Stepko MF Basic principles of higher education in Ukraine in the context of the Bologna process (documents and materials of 2003-2004) / [V. G. Flint. MF Stepko, Ya. Ya. Bolyubash, VD Shinkaruk, etc.] / Edited by VG Kremen. - Ternopil: V. Hnatyuk TSPU Publishing House, 2004. - 147 p.

3. Introduction to the specialty. Road transport: a textbook / VF Glazkov, NI Podolsky. - SPbGASU. - SPb., 2009. - 134 p. 